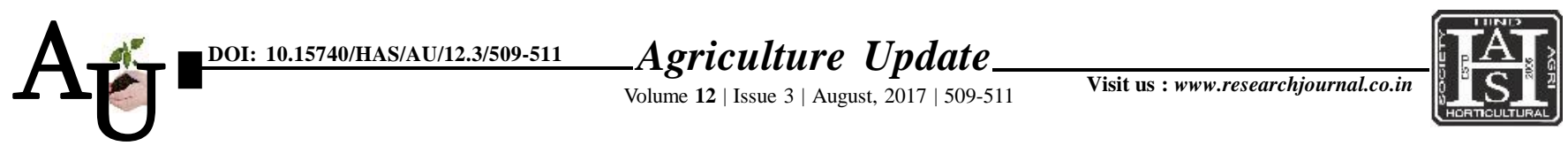

— e ISSN-0976-6847

\title{
Research Note: Front line demonstration of Indian mustard is a path of prosperity for resource poor farmers in rainfed area
}

\section{RAJESH RAI AND SUSHIL KUMAR}

Article Chronicle :

Received :

03.04.2017;

Accepted :

26.07.2017

\section{KeY Words :}

Cluster demonstration

Path, Pilot area,

Prosperity, Resource

poor
Author for correspondence :

\section{RAJESH RAI}

Krishi Vigyan Kendra (C.S.A.U.A.T.), KANPUR (U.P.) INDIA

See end of the article for authors' affiliations
SUMMARY : The study was laidout during 2015-16 at ruined area, situated in Kanpur Dehat. The soil of pilot area is sandy loam, having low fertility status. The improved cultivar Pitambari of Indian mustard was tested with local check in cluster front line demonstration. The main objective of cluster front line demonstration was to increase the productivity of Indian mustard and replace the seed of old cultivars. The cultivar Pitambari was sown in the first week of November with full recommended package of practices. The cultivar Pitambari gave yield by $13.80 \mathrm{q} / \mathrm{ha}$, which was higher over local check by a margin of $5.45 \mathrm{q} / \mathrm{ha}$ or 65.30 per cent. The growth and yield trait were concordant to seed yield.

How to cite this article : Rai, Rajesh and Kumar, Sushil (2017). Front line demonstration of Indian mustard is a path of prosperity for resource poor farmers in rainfed area. Agric. Update, 12(3): 509-511; DOI : 10.15740/ HAS/AU/12.3/509-511. 